\title{
IfHE 総説伎
}

\section{鉄酸化細菌による硫化鉱物の酸化現象*}

\author{
国 吉 信 行 ${ }^{1}$ \\ 原 田 種 卧 $^{2}$
}

\section{1. まえがき}

硫化鉱物を稼行対象とする鉱山の多くは，金属イオンを 多量に含む酸性廃水を生ずる。そして，その中からの銅の 回収は, 純化学的な沈殿銅法により古くから行なわれてい る ${ }^{1 ｝ \text { 。1888年にWinogradskyは, 鉄の酸化を炭酸ガス固定 }$ 用のエネルギー源として増殖する化学無機栄養菌の存在を 提唱した ${ }^{2)}$ が, 鉱山の坑内水中に金属の溶出に重要な働き をする硫黄酸化細菌や鉄酸化細菌の存在が確認され，その 特性や利用について深く検討されるようになつたのは 1950 年代以降である。微生物を用いた鉱石中の特定成分の浸出 すなわちバクテリアリーチングに関しては，これまでTu一 ovinen とKelly ${ }^{2}$ ， 伊藤 ${ }^{3)}$ ，Brierley ${ }^{4)}$ らにより詳しい 総説が発表されている。本稿ではそれらも参考の上さらに 焦点を絞り, 鉄酸化細菌による硫化鉱物の酸化現象とその 応用の可能性について概観し, 読者のご参考に供したい。

\section{2. 細菌 (bacteria) の分類 ${ }^{5)}$}

細菌とは, 分類学上では分裂菌に属する微生物の通称で ある。これは形状，グラム染色に対する陽性または陰性， 運動性，栄養源および酸素要求性などにより分類される。

栄養源の違いからは以下のように分類され，またそのな かには複数の栄養源を利用できるものもおり，そのような 多様性のあるものを通性 ( f acul tat ive ), ないものを偏 性 (obligate) という。

1) 光合成独立栄養細菌 (photoautotrophic bacteri a ）：エネルギー源として光を利用し，おもな炭素源とし て $\mathrm{CO}_{2}$ を利用する。

2) 光合成従属栄養細菌 (photoheterotrophic bacteria ）: エネルギー源として光を利用し，おもな炭素源と して有機化合物を利用する。

3) 化学合成独立栄養細菌 (chemoau totrophic bacteria）: エネルギー源として化学物質を利用し, $\mathrm{CO}_{2}$ を 主要炭素源とする。一般に還元型の無機化合物 $\left(\mathrm{NH}_{3}\right.$, $\mathrm{NO}_{2}^{-}, \mathrm{H}_{2}, \mathrm{H}_{2} \mathrm{~S}, \mathrm{~S}, \mathrm{~S}_{2} \mathrm{O}_{3}^{2-}, \mathrm{Fe}^{2+}$ など) の酸化によりエネ

* 1985 年 3 月 7 日受理

1. 正会員 早稲田大学院理工学研究科博士課程 (現.工博 旭硝子(株))

2. 正会員 工博 早稲田大学教授 理工学部資源工学科
ルギーを獲得する。無機栄養菌ともよぶ。

4）化学合成従属栄養細菌（chemohe terotrophic bacteria ）：化学物質をエネルギ一源とし，有機化合物を 主要な炭素源とする。エネルギー源と炭素源の区別が不明 確な場合が多く，ふつう 1 種類の有機化合物の代謝で両者 を獲得する。ほとんどの細菌はこれに属する。

酸素は一般に溶存酸素の状態で利用され, その要求性の 有無，強弱による分類は以下のようになる。

1）偏性嫌気性菌（obligate anaerobe）：絶対嫌気性 菌ともいう。

2）耐性嫌気性菌（aerotolerant anaerobe）: $\mathrm{O}_{2}$ を 利用できないが， $\mathrm{O}_{2}$ にさらしても死滅しない。

3）通性嫌気性菌（facul tative anaerobe）: $\mathrm{O}_{2}$ を利 用できる場合は利用するが， $\mathrm{O}_{2}$ なしでも増殖できる。

4) 微好気性菌 (microaerobe): 大気濃度より低い $\mathrm{O}_{2}$ 濃度 ( 2 10\%)のみ必要で,より高い濃度では増殖できない。

5) 偏性好気性菌 (obligate aerobe): 増殖に $\mathrm{O}_{2}$ が必 要である。ただし,大気濃度より高濃度の $\mathrm{O}_{2}$ は有害となる。

細菌の分類に関する書物として, Bergey’s Manual of Determinative Bacteriology ${ }^{6)}$ が広く知られており， 多くの細菌の特性が記載されている。

バクテリアリーチングに利用される細菌は，主として鉄 酸化細菌Thiobacillus ferrooxidans (以下 T.f. と略 記する) と硫黄酸化細菌Thiobacillus thiooxidans ( 以下 T.t.と略記する) である ${ }^{a)}$ 。両者は偏性好気性の化 学合成独立栄養菌であるが, $T . f$. の中にはグルコースなど

第1表 Thiobacillus thiooxidans(T.t.)および Thiobacillus ferrooxidans (T.f.) の特徵 ${ }^{6)}$

\begin{tabular}{|c|c|c|c|}
\hline & & $T \cdot t$ & $T \cdot f$. \\
\hline 形 & 状 & 桿状菌 & 桿状菌 \\
\hline 大 & さ & $0.5 \times 1.0 \sim 2.0 \mu \mathrm{m}$ & $0.5 \times 1.0 \mu \mathrm{m}$ \\
\hline ベ & 毛 & 単極毛 & 単極毛 \\
\hline 運 & 動 性 & + & + \\
\hline グ & 么染色 & - & - \\
\hline 基 & 質 & $\begin{array}{l}\text { 硫黄およびその } \\
\text { 化合物 }\end{array}$ & $\begin{array}{l}\mathrm{Fe} \text { (II) 化合物 } \\
\text { 硫黄化合物 }\end{array}$ \\
\hline 窒 & 素 源 & アンモニウム塩 & $\begin{array}{l}\text { アンモニ ウム塩 } \\
\text { 一部硝酸塩も可 }\end{array}$ \\
\hline
\end{tabular}

a）硫黄酸化細菌としてThiobacillus concretivorus も利用され ている。 
第 2 表 $T \cdot f$. により酸化される鉱物 (Duncanら ${ }^{10)}$ による)

\begin{tabular}{|c|c|c|}
\hline 鉱 & 物 & 化学組成 \\
\hline 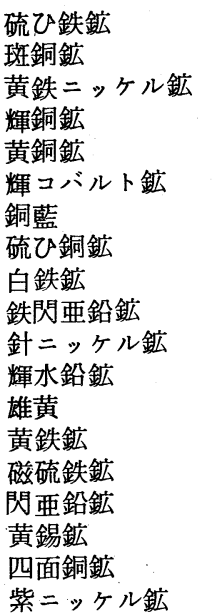 & $\begin{array}{l}\text { Arsenopyrite } \\
\text { Borni te } \\
\text { Bravoi te } \\
\text { Chalcoci te } \\
\text { Chalcopyrite } \\
\text { Cobalti te } \\
\text { Covellite } \\
\text { Enargite } \\
\text { Marcasite } \\
\text { Marmati te } \\
\text { Millerite } \\
\text { Molybdenite } \\
\text { Orpiment } \\
\text { Pyrite } \\
\text { Pyrrhotite } \\
\text { Sphalerite } \\
\text { Stannite } \\
\text { Tetrahedrite } \\
\text { Violarite }\end{array}$ & $\begin{array}{l}\mathrm{Fe}_{2} \mathrm{As}_{2} \mathrm{~S}_{2} \\
\mathrm{Cu}_{5} \mathrm{FeS}_{4} \\
(\mathrm{Ni}, \mathrm{Fe}) \mathrm{S}_{2} \\
\mathrm{Cu}_{2} \mathrm{~S} \\
\mathrm{CuFeS}{ }_{2} \\
\mathrm{Co} \mathrm{AsS} \\
\mathrm{CuS} \\
\mathrm{Cu}_{3}(\mathrm{As}, \mathrm{Sb}) \mathrm{S}_{4} \\
\mathrm{FeS}_{2} \\
(\mathrm{Zn}, \mathrm{Fe}) \mathrm{S} \\
\mathrm{NiS} \\
\mathrm{MoS}_{2} \\
\mathrm{As}_{2} \mathrm{~S}_{3} \\
\mathrm{FeS}_{2} \\
\mathrm{Fe}_{7} \mathrm{~S}_{8} \\
\mathrm{ZnS} \\
\mathrm{Cu}_{2} \mathrm{FeSnS} \mathrm{SnS}_{4} \\
\mathrm{Cu}_{8} \mathrm{Sb}_{2} \mathrm{~S}_{7} \\
(\mathrm{Ni}, \mathrm{Fe})_{3} \mathrm{~S}_{4}\end{array}$ \\
\hline
\end{tabular}

有機物を炭素源とできるものもいるので ${ }^{7) 8)}$, 通性独立栄 養菌とみなされている。上記の書物 ${ }^{6)}$ より拔すいした両者 の特徽を第 1 表に示す。また, 以前は鉄酸化細菌として Ferrobacillus といら属も報告されていたが，その後こ の細菌は硫黄化合物も酸化する機能を持つことが明らかと なり，Thiobacillus 属として一括されるようになつた。

\section{3. 細菌による硫化鉱物の酸化機構 ${ }^{1) 3) 9)}$}

$T . f$. により酸化される鉱物は, Duncanら ${ }^{10)}$ により第 2 表のようにまとめられている。酸化の機構は鉱物により 異なるところがあり，明確でない部分も多いが，およそ次 の 2 つに大別される。1 つは, 細菌が鉱物に直接作用する のではなく, 金属の溶出は細菌により酸化生成した 3 価の 鉄イオンの強力な酸化作用に基づくという間接酸化機構で あり，他方は，細菌が鉱物に対して直接作用するという直 接酸化機構である。

\section{$3 \cdot 1$ 間接酸化機構}

この機構は, i) 化学的な作用により水中に溶出した硫酸 鉄 (II)を細菌が酸化し, ii) 生成した硫酸鉄 (III) が酸化剂と なつて鉱物を酸化, iii) その過程で生成した硫酸鉄 (II) を再 度細菌か酸化する，というサイクルを繰り返すものである。 黄鉄鉣を例にとると, 酸化は以下のように進行する。

$$
\begin{array}{r}
2 \mathrm{FeS}_{2}+7 \mathrm{O}_{2}+2 \mathrm{H}_{2} \mathrm{O} \rightarrow 2 \mathrm{FeSO}_{4}+2 \mathrm{H}_{2} \mathrm{SO}_{4} \\
4 \mathrm{FeSO}_{4}+2 \mathrm{H}_{2} \mathrm{SO}_{4}+\mathrm{O}_{2} \stackrel{\text { 細菌 }}{\rightarrow} 2 \mathrm{Fe}_{2}\left(\mathrm{SO}_{4}\right)_{3}+2 \mathrm{H}_{2} \mathrm{O} \\
\cdots \cdots \cdots \cdots(2) \\
\mathrm{FeS}_{2}+\mathrm{Fe}_{2}\left(\mathrm{SO}_{4}\right)_{3} \rightarrow 3 \mathrm{FeSO}_{4}+2 \mathrm{~S}^{\circ} \quad \cdots \cdots \cdots \cdots(3) \\
\mathrm{FeS}_{2}+7 \mathrm{Fe}_{2}\left(\mathrm{SO}_{4}\right)_{3}+8 \mathrm{~F}_{4} \mathrm{O} \rightarrow 15 \mathrm{FeSO}_{4}+8 \mathrm{H}_{2} \mathrm{SO}_{4}
\end{array}
$$

黄鉄鉱は(1)式のように酸素と水の存在下で徐々に自然酸化 され，硫酸鉄 (II) と硫酸を生ずる。細菌はその保有する酵 素の触媒作用により(2)式のように $\mathrm{Fe}^{2+} \mathrm{Fe}^{3+} に$ 酸化するが, 細菌の存在しない場合, 酸性溶液中で $\mathrm{Fe}^{2+}$ は安定なためこ の反応の進行は緩慢で, Laceyら ${ }^{11)}$ によると $\mathrm{pH} 2.2,31^{\circ} \mathrm{C}$
の条件において T.f.の存在は反応を 50 万倍に加速すると

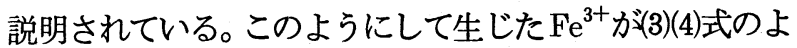
うに黄鉄鉱を酸化し, 再び硫酸鉄 (II) が溶出する。黄銅鉱 の場合も同様に, $\mathrm{Fe}^{3+}$ が酸化剂となり(5)(6)式のように酸化 される。

$$
\begin{aligned}
\mathrm{CuFeS}_{2}+2 \mathrm{Fe}_{2}\left(\mathrm{SO}_{4}\right)_{3} \rightarrow \mathrm{CuSO}_{4}+5 \mathrm{FeSO}_{4}+2 \mathrm{~S}^{\circ} \\
\cdots \cdots \cdots \cdots(5) \\
\mathrm{CuFeS}_{2}+2 \mathrm{Fe}_{2}\left(\mathrm{SO}_{4}\right)_{3}+3 \mathrm{O}_{2}+2 \mathrm{H}_{2} \mathrm{O} \\
\quad \rightarrow \mathrm{CuSO}_{4}+5 \mathrm{FeSO}_{4}+2 \mathrm{H}_{2} \mathrm{SO}_{4} \cdots(6)
\end{aligned}
$$

また，(3)(5)式で生成した硫黄は, T.t.が存在する場合急速 に酸化され硫酸を生ずる。

$$
2 \mathrm{~S}^{\circ}+3 \mathrm{O}_{2}+2 \mathrm{H}_{2} \mathrm{O} \stackrel{\text { 細菌 }}{\rightarrow} 2 \mathrm{H}_{2} \mathrm{SO}_{4}
$$

すなわち, 硫化鉱物の酸化は純化学的な反応であり, 細菌 はその反応サイクルの中て酸化剂の生成に際し触媒作用を なすというのが間接機構である。

なお，(2)式における $\mathrm{Fe}^{2+} \rightarrow \mathrm{Fe}^{3+}+\mathrm{e}^{-}$という反応では約 $7 \mathrm{kcal} / \mathrm{mol}^{2)}$, (7)式の反応では $118 \mathrm{kcal} / \mathrm{mol}^{12)}$ のエネル ギーが放出され，菌はそのエネルギーを $\mathrm{CO}_{2}$ の固定や菌体 成分の合成に利用して増殖する。

鉄を含まない硫化鉱物の中にT.f.により酸化されると 報告されているものもあるが，それは硫化鉱物のほとんど すべてに黄鉄鉱か随伴すること，および微量成分として多 くの場合鉄が含有されることなどに起因するというのが, この機構を支持する研究者たちの主張である。

\section{$3 \cdot 2$ 直接酸化機構}

これは，菌体が硫化鉱物表面に付着し，直接的に酸化す るもので，(1)式や(8)式に対しても触媒作用を与える。

$$
\begin{aligned}
& 2 \mathrm{FeS}_{2}+7 \mathrm{O}_{2}+2 \mathrm{H}_{2} \mathrm{O} \stackrel{\text { 細菌 }}{\longrightarrow} 2 \mathrm{FeSO}_{4}+2 \mathrm{H}_{2} \mathrm{SO}_{4} \cdots\left(\mathrm{I}^{\prime}\right) \\
& 4 \mathrm{CuFeS}_{2}+17 \mathrm{O}_{2}+2 \mathrm{H}_{2} \mathrm{SO}_{4} \\
& \quad \text { 細菌 } 4 \mathrm{CuSO}_{4}+2 \mathrm{Fe}_{2}\left(\mathrm{SO}_{4}\right)_{3}+2 \mathrm{H}_{2} \mathrm{O} \cdots(8)
\end{aligned}
$$

この機構はまだ十分解明されていないが，菌体と鉱物表面 との間で微小な電池が形成され, 鉱物を構成する鉄や硫黄 から電子が細胞膜内の蛋白質系を経由し酸素へ伝達される ためであるとされている113)。

$T . f$. は T.t.ほど強くないが, 無機硫黄化合物の酸化活 性も有しており ${ }^{13)}{ }^{14)}, \mathrm{S}^{2-}$ が菌て酸化されることによる $\mathrm{NiS}, \mathrm{CoS}, \mathrm{Sb}_{2} \mathrm{~S}_{3}, \mathrm{CuS}$ などの酸化について報告がなされ ている ${ }^{13) 15)}$ 。これらの鉱物の鉄を全く含まない系における 酸化・浸出実験や, 電子顕微鏡による鉱粒表面への菌体の 付着および浸出後の鉱粒表面の直接観察 ${ }^{16)}{ }^{17)} に よ り$, 直接 機構の存在が立証されている。

細菌による硫化鉣物の酸化機構として上記の 2 つが提唱 されてきたが, 現在では一般に, 両機構は併存するとみな されている。ただし，それぞれがどのような比率で関与し ているかは, 鉱物の種類や環境などに著しく影響され, さ らに鉱物の浸出とともに環境は変化するため, 明確にする ことが困難である。 


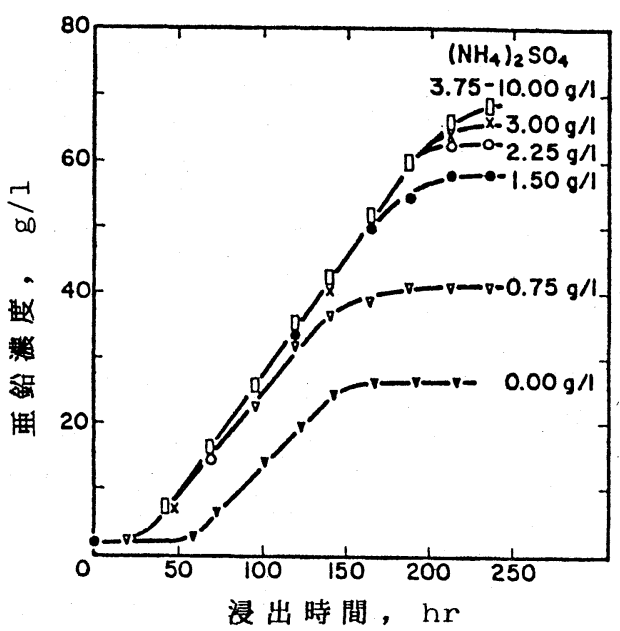

第1図 種々の硫酸アンモニウム濃度における 亜鉛溶出速度 (Torma $ら^{20)}$ による)

\section{4. 細菌の増殖および鉱物の酸化に影響する因子}

\section{$4 \cdot 1 \cdot$ 栄養分}

細菌が生育するのに必要な栄養分 (nutrients) は, a) エネルギー源，b)炭素源，c)窒素源，d）無機塩類，e）ビタ ミンなどの生育因子, に分けられる。T.f.やT.t. は前述 のように化学合成独立栄養菌で, 鉄や硫黄およびその化合 物の酸化をエネルギー源, $\mathrm{CO}_{2}$ を炭素源 $(T . f$. の一部は 有機物も利用）としている。窒素はアミノ酸生合成のため 不可欠な栄養分であり, 主としてアンモニウム塩の形で利用 される。増殖に必要な無機元素としては, リン, 硫黄, マグ ネシウム, カリウムが比較的多量に必要である ${ }^{4) 5 。}$

炭素源である $\mathrm{CO}_{2}$ は酸性溶液中で溶解度が低く，これが 増殖を制限する因子となつている ${ }^{4)}$ 。角田と高森 ${ }^{18)}$ は, 増 殖速度に対する $\mathrm{CO}_{2}$ 濃度の影響を検討し, 気相中の $\mathrm{CO}_{2}$ 濃 度が $1 \%$ 付近までは濃度の上昇とともに増殖速度が増大す ることを示している。

窒素源として利用される $\mathrm{NH}_{4}^{+}$濃度の影響について, Brynerら ${ }^{19)}$ は黄銅鉱の浸出量との関係を調べ, $\mathrm{NH}_{4}{ }^{+}$濃 度は $300 \mathrm{mg} / l$ が最啇であるとしている。またTormaら ${ }^{20)}$ は, 第 1 図のように, 閃覀鉛鉱の浸出における硫酸アンモ ニウム濃度の影響を示している。

実際のダンプリーチングやインプレースリーチングなど では，無機塩類はほとんどの場合母岩中から供給されるが, 実験室においては必要な塩類を添加した培地を使用する。 $T . f$.の培養に用いられる代表的培地を第 3 表に示す。表 に示した 2 種類の培地を用い, Ferrobacillus ferrooxidans ( T.f.と同一種 : 以下 $F . f$. と略記) の増殖を比 較したものが第 2 図であり，9K培地による場合，より活 発に堌殖する様子がわかる ${ }^{22)}$ 。 $9 \mathrm{~K}$ 培地は $T . f$. の増殖に 対しすぐれた培地であると広く認められており, 最近では 大多数の研究で使用されている。Daveら ${ }^{23)}$ は, 閃亜鉛鉱 精鉱からの亜鉛の浸出に対する 9 K培地中の各成分の影響

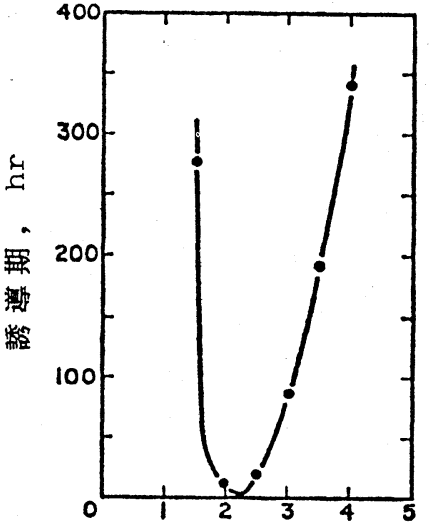

初期 $\mathrm{p} \cdot \mathrm{H}$

第3図誘導期の長さにおよぼ す初期 $\mathrm{pH}$ の影響

(Torma ${ }^{20)}$ による) を用いた $F \cdot f \cdot$ の増殖の比較

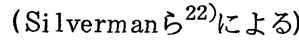

第了表 $T \cdot f$. の培養に用いられる培地 ${ }^{21) 22)}$

\begin{tabular}{l|c|c}
\hline \multicolumn{1}{c|}{ 分 } & Leathen & $9 \mathrm{~K}$ \\
\hline$\left(\mathrm{NH}_{4}\right)_{2} \mathrm{SO}_{4}$ & $0.15 \mathrm{~g}$ & $3.0 \mathrm{~g}$ \\
$\mathrm{KC}$ & $0.05 \mathrm{~g}$ & $0.10 \mathrm{~g}$ \\
$\mathrm{~K}_{2} \mathrm{HPO}_{4}$ & $0.05 \mathrm{~g}$ & $0.50 \mathrm{~g}$ \\
$\mathrm{MgSO}_{4} 7 \mathrm{H}_{2} \mathrm{O}$ & $0.50 \mathrm{~g}$ & $0.50 \mathrm{~g}$ \\
$\mathrm{Ca}\left(\mathrm{NO}_{3}\right)_{2}$ & $0.01 \mathrm{~g}$ & $0.01 \mathrm{~g}$ \\
蒸 留 水 & $1000 \mathrm{ml}$ & $700 \mathrm{ml}$ \\
$10 \mathrm{~N}_{2} \mathrm{SO}_{4}$ & - & $1.0 \mathrm{ml}$ \\
$\mathrm{FeSO}_{4} 7 \mathrm{H}_{2} \mathrm{O}$ & $10 \%(\mathrm{w} / \mathrm{v})$ & $14.74 \%(\mathrm{w} / \mathrm{v})$ \\
& 溶液 $10 \mathrm{ml}$ & 溶液 $300 \mathrm{ml}$ \\
\hline
\end{tabular}

を検討し，未洗浄の試料ではその中に必要な塩類が含まれ ているため, $\left(\mathrm{NH}_{4}\right)_{2} \mathrm{SO}_{4}$ と $\mathrm{K}_{2} \mathrm{HPO}_{4}$ を少量添加するだけ で浸出が進行するが，希硫酸で洗浄した試料では全成分を 添加した 9 K培地が必要であるとしている。

$4 \cdot 2 \mathrm{pH}$

細菌の最適 $\mathrm{pH}$ は一般に中性付近から弱アルカリ性まで $(\mathrm{pH} 6.5 \sim 8.5)^{5)}$ であるが, T.f.やT.t.は酸に対する 耐性の強い特異な菌で, かなりの強酸性溶液中で堌殖する。 これらの細菌の増殖や金属の溶出におよぼす $\mathrm{pH}$ の影響に つい, これまで多くの研究がなされており，そのいくつ かを紹介すれば以下のようである。

Bryner ${ }^{19)}$ は, 黄銅鉱の浸出に対する初期 $\mathrm{pH}$ の影響 を $\mathrm{pH} 1,2,4$ および 6.5 の場合について調べた。その結果， 無菌の場合は酸性度が増すほど浸出量は増大するが，菌を 接種した場合; どのpHでも無菌の場合よりも高い浸出量が 得られることを認めた。またpH 1 では, 無菌の場合と異な り他の pHに比べ浸出量が減少したが，これは菌か耐えら れないほど酸性度が強いためであるとしている。

Malouf とPrater ${ }^{24)}$ は, 黄銅鉱, 閃亜鉛鉱などの浸出 において, 菌の活性が $\mathrm{pH}$ 2.0〜3.5 の間で最も高く, それ より $\mathrm{pH}$ が上昇しても低下しても細菌による酸化速度は低 下すること, さらに pH 6 以上ではほぼ完全に反応が阻害 され，pH 9 では菌が死隇することを認めた。

Razzel1 とTrusse11 ${ }^{25)}$ は, 針ニッケル鉱 $(\mathrm{NiS})$, 斑銅 


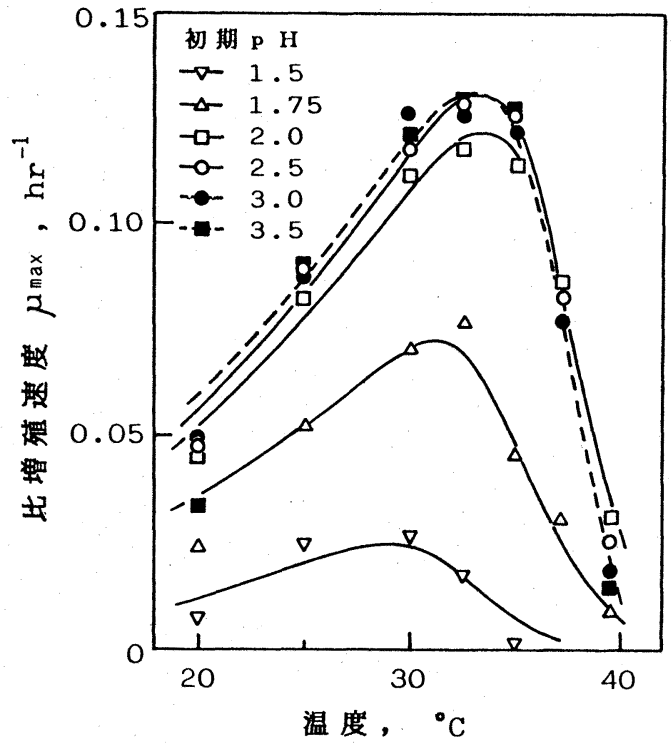

第4図 $T \cdot f$.の増殖速度におよぼす温度と初期 $\mathrm{pH}$ の 影響 ( MacDonaldら ${ }^{26)}$ による)

鉱 $\left(\mathrm{Cu}_{5} \mathrm{FeS}_{4}\right)$, 輝銅鉱 $\left(\mathrm{Cu}_{2} \mathrm{~S}\right)$ について $\mathrm{pH} 2.5$ と 4.0 にお ける浸出量を比較し, 無菌, 着菌の双方とも $\mathrm{pH} 2.5$ におい て，より多量の金属の溶出を認めた。

Torma $~^{20)}$ は, 第 3 図のように閃亜鉛鉱の浸出の場合 に, $\mathrm{pH} 2.0 \sim 2.5$ で誘導期が最も短縮されるとしている。

MacDonald と Clark ${ }^{26)}$ は, 硫酸鉄 (II) を基質とした $T$. $f$. の増殖におよぼす $\mathrm{pH}$ と温度の影響を検討し, 第 4 図の ように初期 $\mathrm{pH} 2.0 \sim 2.5$ で増殖速度は最大となることを認 めた。

\section{$4 \cdot 3$ 温度}

細菌の増殖と温度の関係は，ある温度の範囲では次の Arrhenius の式にしたがう。

$$
\mu=\mathrm{A} \exp (-E \mu / R T)
$$

ただし, $\mu$ : 比増殖速度, $T$ : 絶対温度, $E \mu$ : 増殖の活 性化エネルギー, である。増殖可能な温度には上限と下限 があり，一般に増殖速度が最高に達する最適温度は発育可 能な最高温度より数度低い ${ }^{5)}$ 。

Malouf とPrater ${ }^{24)}$ は, T.f.による $\mathrm{Fe}^{2+}$ の酸化と温 度の関係について検討し, $35^{\circ} \mathrm{C}$ 付近で最大の活性を示すこ とを報告している。

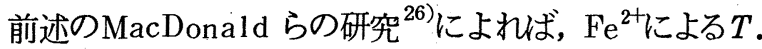
$f$.の増殖において最適温度は $\mathrm{pH}$ により異なり,最適 $\mathrm{pH}$ り低 $\mathrm{pH}$ 側では最適温度は低下している (第 4 図参照)。

Brynerら ${ }^{27)}$ は, T.f.による黄鉄鉱および硫化銅試薬 ( $\mathrm{CuS}$ ) の酸化におよぼす温影響を検討し，これらの 基質においても $T . f$. .最適温度は $35{ }^{\circ} \mathrm{C}$ 付近であることを 認めた。硫化銅の場合, $55^{\circ} \mathrm{C}$ を極小として温度上昇ととも に銅の溶出量が増大するが，これは化学的酸化によるもの と解釈している。

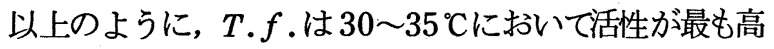
まるが, 最近, より高温下で鉄や硫黄を酸化する能力を持
つ細菌が数種発見され，注目を集めている。その1つは Thiobacillus 属に似た桿状菌で, 生息温度は50 ㄷㄷㄴ にあるが, ただしこの細菌は $\mathrm{CO}_{2}$ を固定できない従属栄養 菌である。また, Sulfolobus 属のある種の細菌は極度に 好熱, 好酸性で, $80^{\circ} \mathrm{C}$ 以上もの高温下で鉄や硫黄を酸化で きる ${ }^{1) 4 ｝ \text { 。ダンプリーチングを考えた場合, 浸出層は黄鉄鉱 }$ などの酸化により高温域となつている関係上, 高温細菌の 研究は重要である。

\section{$4 \cdot 4$ 鉱物の粒度およひ表面積}

粒度や表面積は，鉱物の酸化・浸出に対し多大な影響を およぼす。

Razze11 とTrussel1 ${ }^{25) 28)}$ は, T. $f$. による黄銅鉱の浸 出で試料の粒度および装入量を変化させたところ, 粒度は 微細なほど，装入量は多いほど高い浸出速度が得られた。

Duncan $\breve{~}^{10)}$ は, 黄銅鉱の浸出で, 銅の浸出速度は粒度 が細かくなるほど増大すると指摘している。

Torma $\breve{~}^{20)}$ は高品位硫化亜鉛精鉱を基質とした際の亜鉛 溶出速度におよぼすパルプ濃度および比表面積の影響を検 討した。培地単位体積当りの固体表面積を変化させた場合, 表面積が大きくなるほど溶出速度は増大し，また，表面積 を増大させる手段としてのパルプ濃度の増大と鉱粒の微細 化による比表面積の増大は, 同様の影響を与えている。表 面積がある程度以上に増えると溶出速度の増大の傾向は鈍 化するが，これには $\mathrm{CO}_{2}$ 量の制限が影響している。第 5 図 のように, 空気中の $\mathrm{CO}_{2}$ 濃度が $0.03 \%$ ( 大気中の濃度 ) か ら $1 \%$ までは, 濃度上昇とともに最大溶出速度が増大して いる ${ }^{29)}$ 。しかしそれ以上の濃度では変化がなく, $\mathrm{CO}_{2}$ 以外 の要因が作用しているものと考えられる。

Pinche ${ }^{30)}$ は, 2 種類の黄銅鉱精鉱を用い, 粒度別にT. $f$.による浸出を行なつた。その結果, 浸出速度の小さい試 料の場合, 粒径 $7 \mu \mathrm{m}$ 以上では浸出量は比表面積に依存す

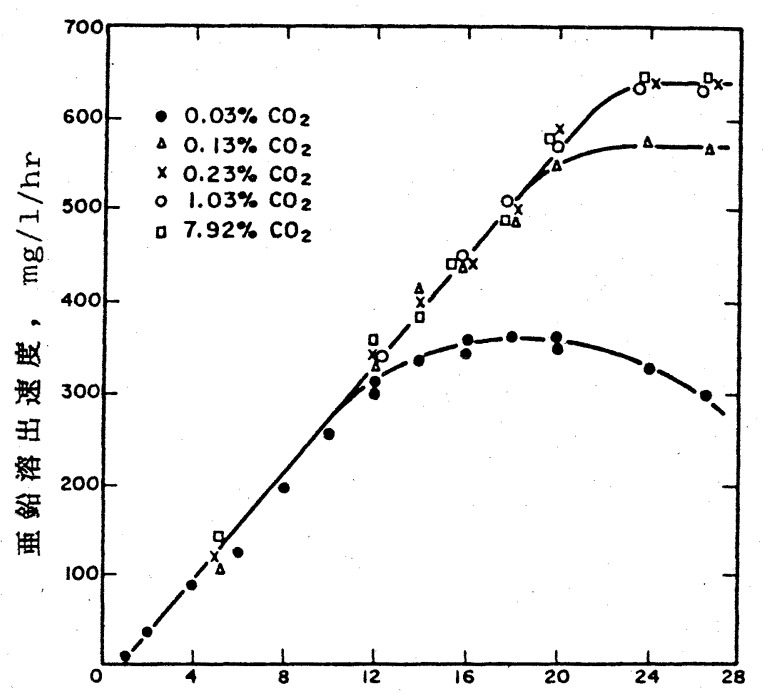

初期パルプ濃度， g/100ml

第 5 図 異なる $\mathrm{CO}_{2}$ 分圧下に拉ける亜鉛溶出速度におよ ぼすパルプ濃度の影響 ( Torma ら ${ }^{29)}$ による) 


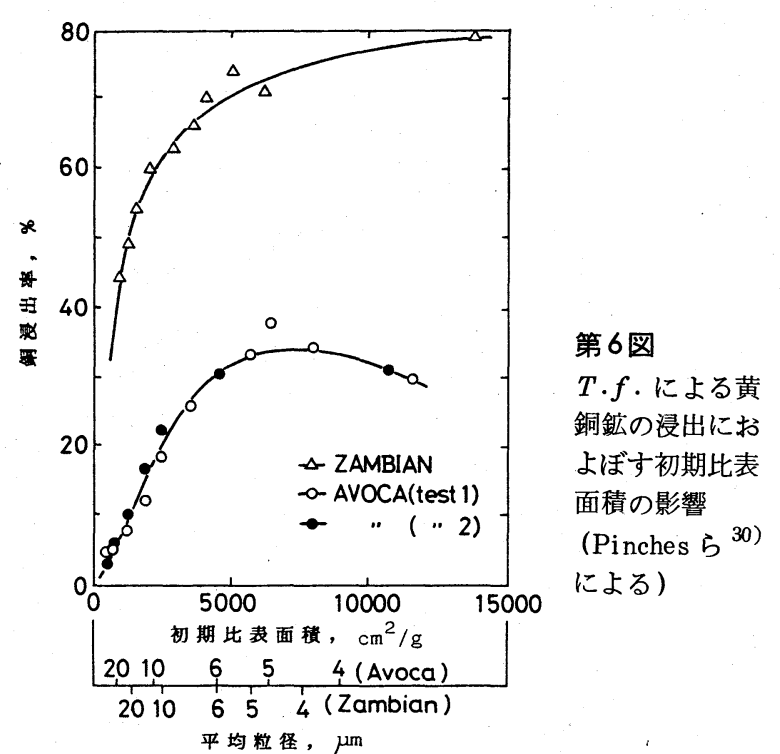

るが, それより微細になるとより複雑な関係になること (第6図), また計算で求めた浸出の深さは粒径 $7 \mu \mathrm{m}$ 以 上では一定で，それより微細な粒子ではより浅いことが明 らかとなつた。この現象をPinchesらは, 菌体と鉱粒の相 対的な大きさや微粒子の凝集を含めた, 細菌と鉱物の反応 における幾何学的影響によるものとしている。

Kingma とSilver ${ }^{31}$ は, 浸出前後の黄銅鉱の粒度分布 より, 細かい粒子が優先的に浸出されていると指摘してお

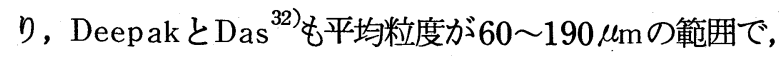
粒度の減少とともに黄銅鉱の浸出速度が増大すると述へてて いる。

\section{$4 \cdot 5$ 鉱物に対する菌体の適応}

$\mathrm{Fe}^{2+}$ により増殖させた菌を他の基質を含む培地に接種 した際，しばしば長い誘導期が認められ，また，硫化鉱物 の酸化速度は同一鉱物での前培養により増大するという報 告 ${ }^{2)}{ }^{33)}$ もあり, 対象となる鉱物への菌体の適応は重要な問 題である。

Landesman ${ }^{34)}$ は, 硫黄, 硫酸鉄 (II), 黄銅鉱それぞ れで増殖させた T.f. を用い，同様の 3 種の基質の酸化を 比較した。その結果，すべての基質に対し硫酸鉄 (II) 培養 菌が有効で, とくに硫酸鉄 (II) に対しては硫黄培養菌の 50 倍，黄銅鉱培養菌の10倍の速度て酸化した。

Duncanら ${ }^{35)}$ は, $\mathrm{Fe}^{2+}$ および黄銅鉱で培養した $T . f$. .を 用いて, 黄銅鉱, 黄鉄鉱の酸化について検討した。鉄酸化 の阻害剂であるアジ化ナトリウム $\left(\mathrm{NaN}_{3}\right)$ および硫黄酸化 の阻害剂N-e thy lmal eimide ( $\mathrm{NEM}, \mathrm{C}_{6} \mathrm{H}_{7} \mathrm{O}_{2} \mathrm{~N}$ ) を使用 し, 酸素消費量との関係加ら以下の結果を得た。黄銅鉱培 養菌では，黄銅鉱の酸化で消費した酸素の $68 \sim 74 \%$ は硫黄, 25 30\%は鉄 (II)の酸化に対するもので, 黄鉄鉱の酸化に おける酸素消費はすべて硫黄の酸化に対するものである。 $\mathrm{Fe}^{2+}$ 培養菌では, 黄銅鉱の酸化は $2 \mathbf{E}^{-} に$ 進行し, 初期の 酸化速度の大きい段階では酸素消費の80〜90\%は鉄 (II)の
酸化に対するもので，2段目の遅い段階では黄銅鉱培養菌 と同様であつた。また，黄鉄鉱の酸化は黄銅鉱培養菌によ る場合よりはるかに速く, それは消費した酸素の $20 \sim 30 \%$ しか硫黄の酸化に使用されないことから, 鉄 (II) の酸化速。 度が大きいためであるとしている。

Si lver と Torma ${ }^{15}$ ) は, 硫酸鉄 (II), 方鉛鉱精鉱 (閃亜 鉛鉱, 黄鉄鉱, 黄銅鉱も含有 ) および黄銅鉱精鉱 (黄鉄鉱, 磁硫鉄鉱，閃亜鉛鉱も含有）それぞれで培養した $T . f$.を 用い，14種の基質における酸素消費，金属の溶出および $\mathrm{CO}_{2}$ の固定について検討した。その結果, i) 黄銅鉱, 輝銅 鉱, 銅藍, 針ニッケル鉱, 輝安鉱などでは菌が異なつても 酸素消費にほとんど变化がない，ii)黄鉄鉱における酸素消 費は方鉛鉱精鉱培養菌より他の 2 つの菌の方がはるかに大 きい, iii)方鉛鉱精鉱培養菌では純粋な方鉛鉱や方鉛鉱精鉱 をエネルギー源としても $\mathrm{CO}_{2}$ を固定できる, など, 菌の培 養方法により異なる傾向が認められた。

Thakurら ${ }^{36)}$ は, T.f.による銅鉱石からの銅の浸出で, 菌を事前に $0.005 \mathrm{M}$ 程度の硫酸銅溶液を用いて銅イオンに 対し適応させることにより, Leathen 培地のみで培養し た菌の $2 \sim 2.5$ 倍の浸出量が得られることを認めた。

KingmaとSilver ${ }^{31)}$ は，T.f.による黄銅鉱および方 鉛鉱の酸化で, 黄銅銨で培養した菌は黄銅鉱に対して活性 を持ち, 方鉛鉱で培養した菌は方鉛鉱に対し活性を持つと 述べている。

Roy と Mishra ${ }^{37)}$ は; 黄鉄鉱をT.f. て酸化する場合, $\mathrm{Fe}^{2+}$ で増殖させた菌では誘導期か認められるが, 黄鉄鉱 で前培養を行なつた菌ではそれが消隇することを示してい る。

また筆者らの研究 ${ }^{38)}$ でも, 第 7 図のように, T.f.の前 培養条件により黄鉄鉱の酸化・浸出挙動が変化することが 認められている。ここで, Aは $9 \mathrm{~K}$ 培地で1週間前培養した 場合, $\mathrm{B}$ は $9 \mathrm{~K}$ 培地による 3 日間の培養を 5 回以上繰り返し た場合，およびCは黄鉄鉱を基質として前培養した場合で, 黄鉄鉱で前培養すると誘導期か湿著に短縮される。

\section{$4 \cdot 6$ 溶存イオンおよひ阻害剤の影響}

$T . f$. は, 他の多くの細菌と比較してきわめて高い金属 イオンへの耐性を有しているが, その耐性は菌株によつて しばしば変化し, 多くの菌株に対する共通のデータは乏しい。

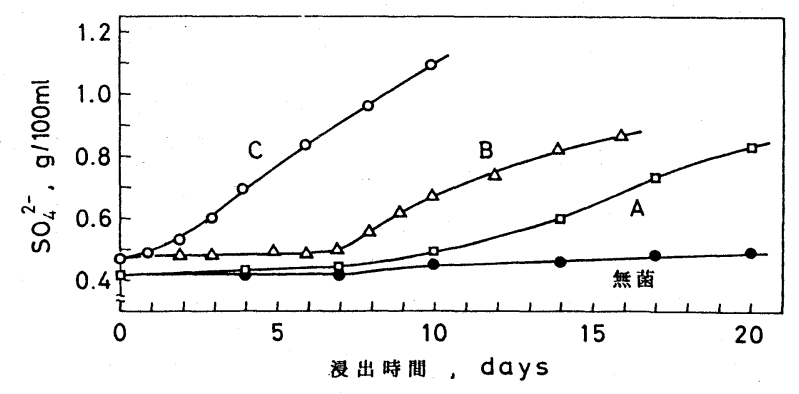

第7図 各前培養条件 $(\mathrm{A}, \mathrm{B}, \mathrm{C})$ の $T \cdot f$. による黄鉄鉱 浸出液中の硫酸イオン濃度の変化 ${ }^{38)}$ 
第 4 表 $T . f . に よ る$ 鉄酸化におよぼす陰イオンの影響 2$)$

\begin{tabular}{|c|c|c|c|}
\hline 化 合 物 & 濃度 $(M)$ & 阻害作用 (\%) & 文献 \\
\hline ひ酸ナトリウム & 0.025 & 0 & \\
\hline 亜ひ酸ナトリウム & 0.025 & 0 & \\
\hline フッ化ナトリウム & 0.00025 & 100 & 40 \\
\hline シアン化ナトリウム & 0.00024 & 99 & \\
\hline モリブデン酸ナトリウム & 0.001 & 85 & * \\
\hline アジド & 0.00025 & 100 & 40 \\
\hline 硝酸ナトリウム & 0.07 & 40 & \\
\hline & 0.094 & 100 & \\
\hline 塩化ナトリウム & 0.086 & 50 & 28 \\
\hline & 0.172 & 90 & \\
\hline 塩化カリウム & 0.257 & 90 & \\
\hline 硫酸ナトリウム & 0.14 & 0 & 28,40 \\
\hline
\end{tabular}

* Tuovinen ら ( 未発表)

第 4 表は, Tuovinen ${ }^{2)}$ によりまとめられたT.f.の鉄 酸化活性におよぼす各種陰イオンの影響, また第 5 表は, 今井 ${ }^{39)}$ によるT.f.の増殖および鉄酸化におよぼす各種重 金属塩類の影響である。T.f. に対し最も阻害作用の強い 重金属イオンは水銀および銀イオンで，次いで錫イオンで あることがいえる。コバルト，亜鉛，ニッケル，銅，カド ミウム,クロム (III), 鉛イオンなどに対しては比較的高濃 度 $\left(10^{-3} \sim 10^{-1} \mathrm{~mol} / l\right)$ まて耐えることができる。陰イオ ンは吪酸, 亜砣酸および硫酸イオンを除いて阻害作用を呈 し, とくにフッ素, シアン, モリブデン酸, アジドなどの 作用は強い。硝酸イオンや塩素イオンも高濃度では阻害作 用を示し, Vorreiter ${ }^{41)}$ は低品位銅鉱石のカラムを用 いた浸出で塩化ナトリウム溶液が $T . f$.の活性を著しく減 少させるとしているが, 硝酸イオンは $10^{-3} \mathrm{~mol} / l$ 以下 ${ }^{7)}$ で, 塩素イオンは $10^{-2} \mathrm{~mol} / l$ 以下 $^{39)}$ で菌の生育を阻害し ないとの報告もされている。また，重金属の阻害作用はそ れがイオンとして存在する場合に起こり, 不溶性化合物の 状態では無害であることが示唆されている。

Babich とS totzky ${ }^{42) 43)}$ は，T.f.などとは異なるが， 多くの細菌の増殖におよぼすカドミウムの阻害作用と粘土 鉣物による防御作用について検討した。モンモリロナイト， カオリナイトとも $\mathrm{dd}$ の阻害作用を減少させるが, 効果はモ ンモリロナイトの方がはるかに大きく，それは粘土鉣物の 陽イオン交換容量 ( CEC) に起因するとしている。粘土鉱 物ばかりでなく，多くの鉱物が陽イオンを吸収し ${ }^{4)}$, また, 酸化過程での鉄塩 (III) の沈殿生成も重金属イオンとの共沈 現象などにより，それらの除去に寄与すると考えられる。 さらにSugioら ${ }^{44)}$ は, T.f.による硫化ュバルトの浸出で $\mathrm{Co}^{2+}$ の阻害作用を $\mathrm{Fe}^{2+}$ の添加が防御し, 同様の作用が錫, ニッケル, 亜鉛, 銀および水銀イオンに対しても認められ ることを報告している。有害イオンの存在する環境におい ては, 菌体の順応とともに, 以上のような現象の利用も考 慮される必要があろう。

各種有機試薬による阻害作用についても研究されている。 $T . f$. を選鉱操作と組合せて利用する場合など, 界面活性 剂の影響を把握することは重要であり, 硫化鉱物精鉱や石 炭の貯蔵, 運搬中での酸化抑制の観点からも阻害阂に関す
第 5 表 菌体の増殖ならびに培地中の鉄酸化におよぼす 重金属イオンの影響 (今井 ${ }^{39}$ による )

\begin{tabular}{|c|c|c|c|}
\hline \multirow{2}{*}{\multicolumn{2}{|c|}{$\begin{array}{c}\text { 添加した重金属塩類の種類と濃度 } \\
(\mathrm{M})\end{array}$}} & \multicolumn{2}{|c|}{ 阻 害 作 用 } \\
\hline & & \multirow{2}{*}{$\frac{\text { 菌体の増殖 }}{-}$} & 培地の鉄酸化 \\
\hline \multirow{4}{*}{$\begin{array}{l}\mathrm{Cd} \mathrm{SO}_{4} \\
\mathrm{Zn} \mathrm{SO} \\
\mathrm{Cu} \mathrm{SO}_{4} \\
\mathrm{Cr}_{2}\left(\mathrm{SO}_{4}\right)_{3} \\
\end{array}$} & $10^{-4} \sim 10^{-2}$ & & - \\
\hline & $10^{-5} \sim 10^{-3}$ & - & - \\
\hline & $10^{-4} \sim 10^{-2}$ & - & - \\
\hline & $10^{-4} \sim 10^{-2}$ & - & - \\
\hline \multirow[t]{3}{*}{$\mathrm{PbNO}_{3}$} & $10^{-5}$ & 1 日遅れ & 1 日遅れ \\
\hline & $10^{-4}$ & & " \\
\hline & $10^{-3}$ & 2 日遅れ & 2 日遅れ \\
\hline \multirow[t]{3}{*}{$\mathrm{Na}_{2} \mathrm{MoO}_{4}$} & $10^{-4}$ & - & - \\
\hline & $10^{-3}$ & 1 日遅れ & 1 日遅れ \\
\hline & $10^{-2}$ & 90\%阻害 & $90 \%$ 阻害 \\
\hline \multirow[t]{3}{*}{$\mathrm{P}_{2} \mathrm{O}_{5} \cdot 24 \mathrm{M}_{0} \mathrm{O}_{3}$} & $10^{-5}$ & 2 日遅れ & 1 日遅れ \\
\hline & $10^{-4}$ & 55\%阻害 & 3 日遅れ \\
\hline & $10^{-3}$ & $60 \%$ 阻害 & $30 \%$ 阻害 \\
\hline \multirow[t]{2}{*}{$\mathrm{SnCl}_{2}$} & $10^{-5} \sim 10^{-4}$ & - & - \\
\hline & $10^{-3}$ & $100 \%$ 阻害 & $94 \%$ 阻害 \\
\hline \multirow[t]{3}{*}{$\mathrm{AgNO}_{3}$} & $10^{-5}$ & 2 日遅れ & 3 日遅れ \\
\hline & $10^{-4}$ & $100 \%$ 阻害 & 100\%阻害 \\
\hline & $10^{-3}$ & $100 \%$ 阻害 & $100 \%$ 阻害 \\
\hline \multirow[t]{3}{*}{$\mathrm{HgCl}_{2}$} & $10^{-5}$ & $80 \%$ 阻害 & $40 \%$ 阻害 \\
\hline & $10^{-4}$ & $100 \%$ 阻害 & $80 \%$ 阻害 \\
\hline & $10^{-3}$ & $100 \%$ 阻害 & $85 \%$ 阻害 \\
\hline \multirow[t]{3}{*}{$\mathrm{HgNO}_{3}$} & $10^{-6}$ & - & - \\
\hline & $10^{-5}$ & $100 \%$ 阻害 & $50 \%$ 阻害 \\
\hline & $10^{-4}$ & $100 \%$ 阻害 & $80 \%$ 阻害 \\
\hline
\end{tabular}

る研究が必要となる。

Duncanら ${ }^{35)}$ は, 前節で記述したように, 阻害阂の影響 は菌の培養方法により変化することを示している。

Tut tle とDugan ${ }^{45)}$ は, $\mathrm{Fe}^{2+}$ によるT.f.の増殖におよ ぼす多種の低分子量有機化合物の阻害作用を検討し, 鉄酸 化の阻害効果に寄与する主たる要因は, 有機分子の相対的 な電気陰性度であると述べている。さらに有機阻害剤の作 用としては，i)鉄酸化酵素系への直接的な影響, ii)細胞外 での $\mathrm{Fe}^{2+}$ との非生物的な反応, iii)鉄酸化におけるリン酸 塩, 硫酸塩の役割の妨害, iv)細胞膜の破壊, などが考えら れるとしている。

DuganとApe ${ }^{46)}$ は, ラウリル硫酸ナトリウムおよび安. 息香酸ナトリウム水溶液のT.f.およびT.t.に対する阻害 作用により, 硫黄含有量の多い石炭ボタからの酸性廃水を 減少できることを報告している。またOnyskoら ${ }^{47)}$ は, ラ ウリル硫酸ナトリウム, ソルビン酸および安息香酸が $T$.

\section{$f$. による鉄酸化を著しく阻害することを示している。}

\section{$4 \cdot 7$ 2次鉱物の生成}

Burkin ${ }^{48)}$ は, 浸出中に起こりうる固体相の変化として 次の 3 つをあげている。i)固体が溶解し, 溶液中から他の 化合物として沈殿する。ii)ある元素は溶解し，そのまま溶 液中に残留する。iii) 溶液中のイオンまたは分子が新たな固 体相を形成するため, 結晶格子中にはいり込む。浸出系内 における沈殿生成や鉱粒表面での新たな鉱物相の生成とい つた 2 次鉱物の生成は, 目的とする鉱物の浸出挙動に多大 な影響をおよぼし，多くの場合浸出速度を低下させる。

Silver と Torma ${ }^{15)}$ は, $\mathrm{Cu}_{2} \mathrm{~S} の T . f$. による浸出残渣 


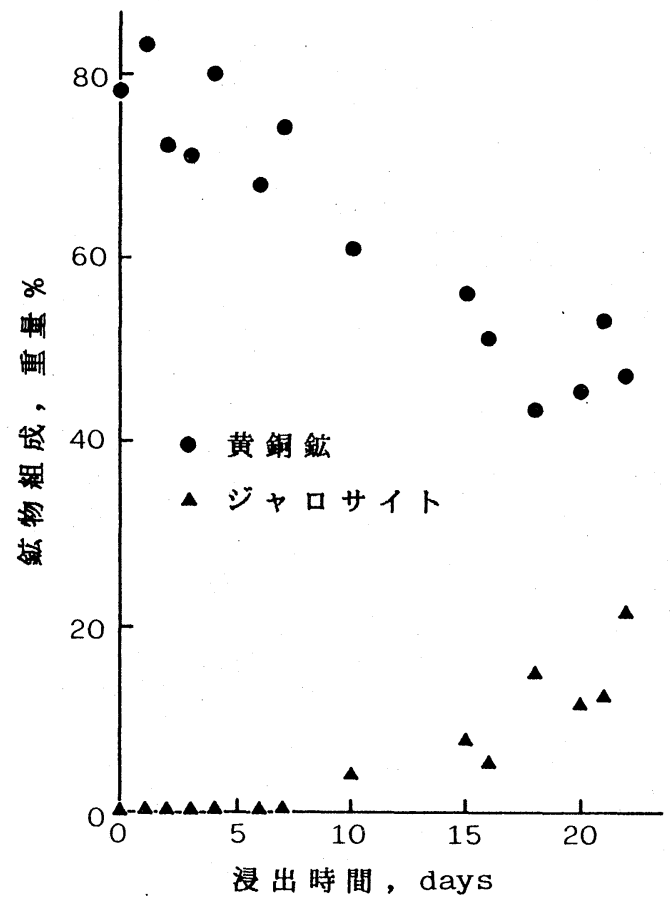

第 8 図 $T \cdot f$. 存在下における黄銅鉱精鉱中の鉱物組 成の変化 (Kingma $5^{31)}$ による)

中に, $\mathrm{Cu}_{9}-\mathrm{x} \mathrm{S}_{5}, \mathrm{Cu}_{3} \mathrm{SO}_{4}(\mathrm{OH})_{4}, \mathrm{CuS}$ および金属銅を認 めた。

KingmaとSilver ${ }^{31)}$ は, T.f.による黄銅鉱の酸化に際 し，第 8 図のように銅の溶出とともに鉄がジャロサイトを 形成することを示している。

Madgwi ck と Ral ph ${ }^{49)}$ は, 低品位銅鉱石の浸出で, 銅 の浸出率50\%以前の段階で銅の酸化物を含んだ非晶質の水 酸化鉄が沈殿し浸出が停止するが, 硫酸を添加しpH1.5 程 度で沈殿物を溶解, 除去したのち $\mathrm{pH} 2$ にもどすことに より，浸出が再度進行すると述べている。

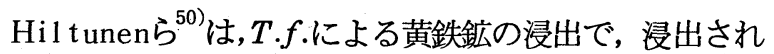
た鉄の大部分は微細に分散したコロイドまたは有機錯体の 形で存在し, 残渣中にはジャロサイトの結晶が生成するこ とを認めた。

Murr と Mehta ${ }^{51)}$ は, 黄銅鉱と黄鉄鉱を銅線で結合し, 耐高温性の鉄酸化細菌の存在する $\mathrm{pH} 2.3,55^{\circ} \mathrm{C}$ 溶液中で, 電気化学的反応を細菌の触媒作用により促進させた際の黄 銅鉱表面の 2 次生成物を電子線回折により同定した。その 結果, $\mathrm{Cu}, \mathrm{Cu}_{5} \mathrm{FeS}_{4}, \mathrm{Cu}_{2} \mathrm{~S}, \mathrm{CuS}$, さらに複雑な化合物 が検出された。また, 単体硫黄は菌が存在しない場合のみ 生成し, 着菌した場合は酸化され硫酸となる。

Ivarson ${ }^{51)}$ は, $\mathrm{K}^{+}, \mathrm{NH}_{4}{ }^{+}$および $\mathrm{Na}^{+}$を含む $\mathrm{FeSO}_{4}$ 溶液にT.f.を接種した際に生成するジャロサイト類鉱物 について検討し，それぞれのイオンの結晶に取りこまれる 速度は, $\mathrm{K}^{+}>\mathrm{NH}_{4}{ }^{+}>\mathrm{Na}^{+}$の順で, 2 種類が共存する場合 は固溶体を形成することを認めた。

Lazarof $\mathrm{f}^{53)}$ は, 酸性溶液中で $T . f$. により $\mathrm{Fe}^{2+}$ を 酸化する場合, ジャロサイトの結晶, 非晶質の塩基性硫酸
鉄もしくはその両者が生成することを示している。とくに ジャロサイトの結晶は, 過剰の $\mathrm{SO}_{4}^{2+}$ と適当な 1 価陽イオ ンが存在する場合に生成するとしている。

\section{$4 \cdot 8$ 電気化学的反応の影響}

2 種類の硫化鉱物が酸性溶液中で接触した場合, 電極電 位の高い鉱物 (貴な鉱物 ) はカソードとしてふるまい，低 い鉱物 (卑な鉱物) はアノードとしてふるまう。カソード 上では(10)式，アノード上では(11)式の反応が起こり, 両式を 合わせると(12)式となり，卑な鉱物中の金属イオンが溶出す る $^{54)}$ 。

$$
\begin{aligned}
& 1 / 2 \mathrm{O}_{2}+2 \mathrm{H}^{+}+2 \mathrm{e}^{-}=\mathrm{H}_{2} \mathrm{O} \quad \cdots \cdots \cdots \cdots \cdots \cdots \cdots \cdots(10) \\
& \mathrm{MS}=\mathrm{M}^{2+}+\mathrm{S}^{\circ}+2 \mathrm{e}^{-} \quad \ldots \ldots \ldots \ldots \ldots \ldots \ldots \ldots \ldots \ldots \text { (11) } \\
& \mathrm{MS}+1 / 2 \mathrm{O}_{2}+2 \mathrm{H}^{+}=\mathrm{M}^{2+}+\mathrm{S}^{\circ}+\mathrm{H}_{2} \mathrm{O} \quad \cdots \cdots \cdots \cdots(12)
\end{aligned}
$$

各種硫化鉱物の電極電位を比較すると, 黄鉄鉱は黄銅鉱, 輝銅鉱, 銅藍, 方鉛鉱および閃亜鉛鉱などよりも貴な鉱物 であり，酸性溶液中で黄鉄鉱がこれらの鉱物と接触すると， 接触した鉱物は酸化が促進される。以上のような電気化学 的酸化と細菌による酸化の相互作用について検討されてお $\eta^{54)}{ }^{55)}$, 黄鉄鉱と黄銅鉱が接触した場合の反応は, Mur r ${ }^{9)}$ により第 9 図のようにモデル化されている。黄鉄鉱, 黄銅 鉱，閃覀鉛鉱の結晶を銅線で結合した際の銅および亜鉛の 溶出量を示したのが第10図, 第 11 図である ${ }^{54)}$ 。黄銅鉱, 閃 亜鉛鉱単独の場合より黄鉄鉱と結合した方が, また, 無菌 よりT.f.を接種した方が金属の溶出量は増大している。 -200meshの試料を用いた場合は, 黄銅鉱に添加する黄鉄 鉱の量が多くなるほど ( $1: 1$ までについて), 銅の溶出量 は増えている。

鴻巣, 鈴木, 井上, 下飯坂ら ${ }^{56)}$ は, 異なる基質で培養し た数種の菌を用い, 黄鉄鉱を含有する銅浮選精鉱の浸出に おける電気化学的浸出の効果について検討したところ, $\mathrm{CuS}$ を基質として培養した菌では黄銅鉱が優先的に浸出さ れ。浸出量は無菌の場合より 50 \%増大したが，Sまたは $\mathrm{FeSO}_{4}$ 培養菌では黄鉄鉱が優先的に浸出された。すなわ ち, 培養基質の違いにより電気化学的効果を増大させる場 合と逆の場合のあることを示している。

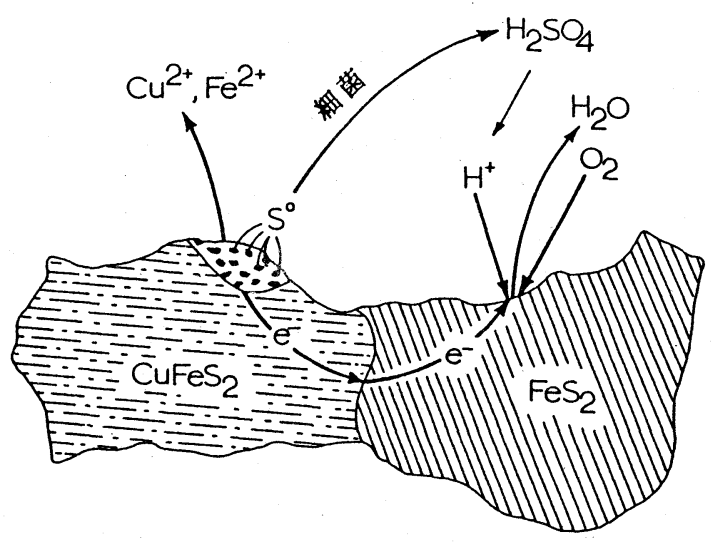

第9図 電気化学的酸化の概略図 (Murr ${ }^{9)}$ による) 


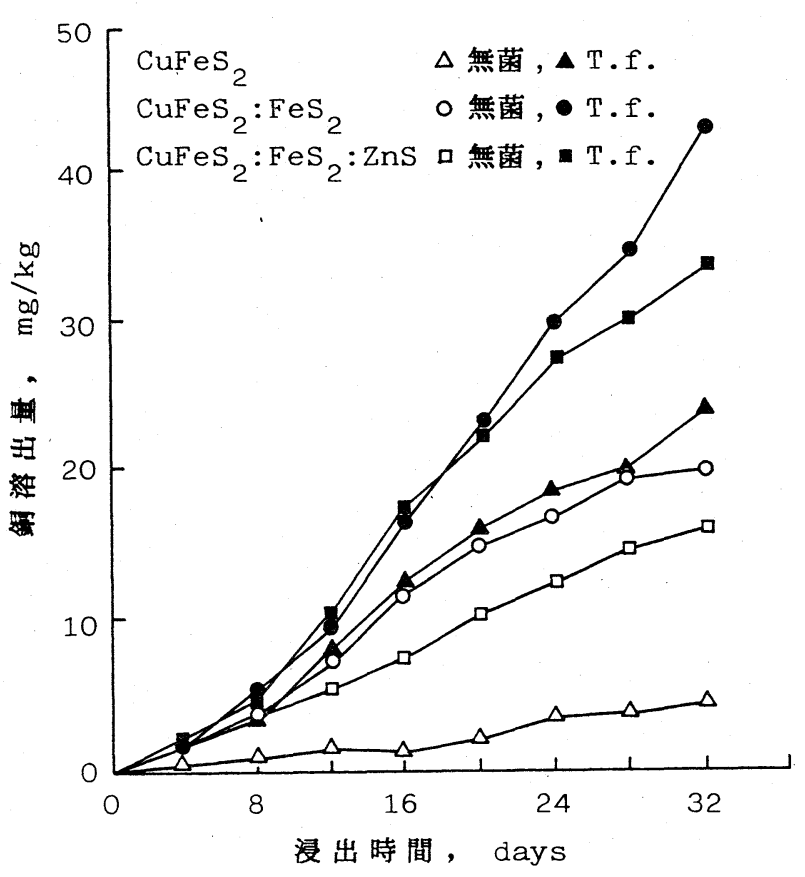

第10図 黄銅鉱単独または他鉱物と電気化学的に結合 した際の銅溶出速度 (Mehta ら ${ }^{54)}$ による)

\section{5. 細菌による石炭の脱硫}

石炭中に含まれる硫黄分は, 石炭の有機化合物として含 まれる有機質硫黄と，黄鉄鉱や白鉄鉱などの硫化鉄鉱物お よび石膏などの硫酸塩鉱物の形で含まれる無機質硫黄の 2 つに大別される。このうち, 無機質硫黄を細菌により溶解, 除去しようという試みが多くなされている。

Silverman $~^{57)}$ は, 石炭化度の異なる数種の石炭試料 のF.f.による脱硫を試みた。粒度が微細な場合に細菌の 作用はより効果的で, ある石炭では $80 \%$ の黄鉄鉱が除去さ れた。石炭化度による脱硫されやすさの順序は, 瀝青炭> 亜瀝青炭>亜炭となり，この原因は石炭化度の低いものほ ど酸を中和寸る作用が強いためであると解釈している。

DetzとBarvinchak ${ }^{58)}$ は，T.f.および好熱性のSulfolobus 属の細菌により, 石炭の脱硫が効果的に行なわれ ることを認めたのち操業コストを試算し, 従来法に比べ細 菌による脱硫法が最も安価であることを示している。

Hoffmann ら ${ }^{59)}$ は, T.f.およびT.t.の異なる菌株を用 い, 数種の石炭の脱硫に影響する因子を検討し, 石炭中の 黄鉄鉱の浸出速度は露出した黄鉄鉱の表面積に比例するこ とを認めた。黄鉄鉱質硫黄分の比較的高い試料では, パル ブ濃度 $20 \%$ 以下, 粒径 $74 \mu \mathrm{m}$ 以下の条件において, 8〜 12 日間で，90〜98\%の脱硫が澾成された。

国内の石炭については, 三池炭の脱硫に関する報告 ${ }^{60) 61)}$ がある。 $-20 \mu \mathrm{m}$ に粉砕した試料をT.f.により 5 週間浸出 して, 無機質硫黄の $67 \%$ が除去された。この程度の浸出率 にとどまつた原因は, この石炭試料中の硫化鉄の多くが 1 $\mu \mathrm{m}$ 前後の微粒子として存在するので, 石炭に包まれたまま

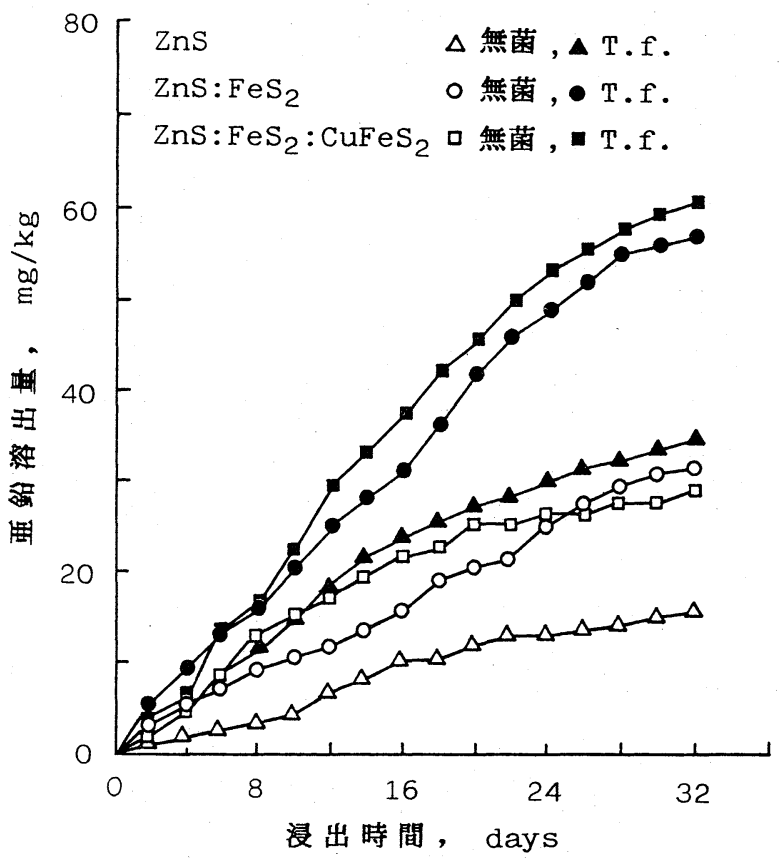

第11図閃亜鉛鉱単独または他鉱物と電気化学的に結 合した際の亜鉛溶出速度 (Mehta ら ${ }^{54)}$ による)

浸出液に接触しない硫化鉄粒子があるためと判断している。 近年，エネルギー資源としての石炭が見直され，また， 微粉炭としての利用が検討されるなど, 細菌による脱硫に 有利な面も生じている。そのため上記以外にも多くの研究 が遂行されて㧍り，今後の発展が期待される。

\section{6. 他操作との組合せ}

細菌による浸出を他の分離操作と組合せる力法は 2 つに 大別できる。1つは，ある成分をすべて浸出し，その後の 処理に他操作を適用する方法, 他方は, ある分離操作の前 処理として細菌の作用を利用するものである。

前者の例として, Torma とSubramani an ${ }^{62)}$ は, 硫化鉛 精鉱中の銅, カドミウム, 西鉛の回収法として T.f. を利 用したプロセスを提示している。すなわち, 鉛精鉱を細菌 で浸出し, 鉄, 銅, カドミウム, 亜鉛を浸出液中に, 鉛を $\mathrm{PbSO}_{4}$ の形で残渣として分離したのち, 浸出液から沈殿分 離法やセメンテーション法でそれぞれの有価金属を回収す る方法である。複雑硫化鉱の処理法としてCarta ${ }^{63)}$ も 同様の方法を示している。

後者に関連した研究例は, これまで非常に少数である。

Capes ${ }^{64)}$ は, 石炭中の黄鉄鉱質硫黄分除去のため選択 造粒法を適用し，その前処理としてT.f.を使用した。黄 鉄鉱の表面を親水性化する目的で数種の化学試薬を使用し た場合には，50\%以上の黄鉄鉱を除去することは困難であ つたが，T.f.を使用した場合には，80\%の黄鉄鉱か除去さ れたことを報告している。

Law rence とBruynes t eyn ${ }^{65)}$ は, 青化製鍊の前処理と してT.f. で鉱石中の黄鉄鉱を酸化することにより, 金, 銀の実収率が向上することを報告している。使用した 3 試 


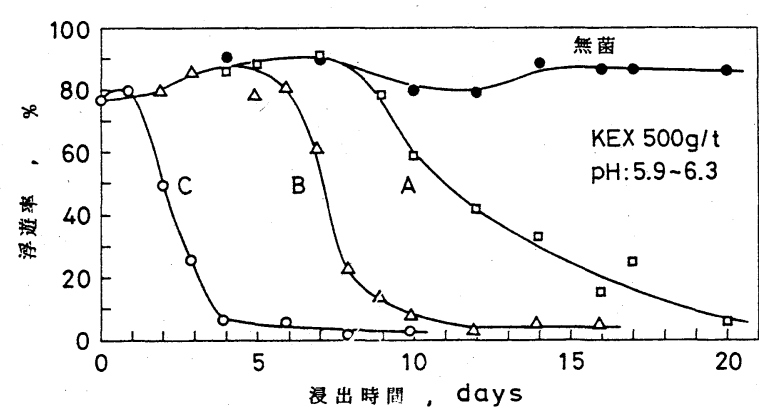

第12図 各前培養条件 $(\mathrm{A}, \mathrm{B}, \mathrm{C})$ の $T \cdot f$.による浸出時 間と黄鉄鉱浮遊率の関係 ${ }^{38)}$

料を直接青化法で処理した場合の金の実収率はそれぞれ， 24\%, 60〜78\%, 80〜86\%であつたが, T.f.で試料中の黄 鉄鉱の80〜88\%を酸化したのちでは, それぞれ，81\%,90 \%以上，98\%以上となつた。この結果をもとに, 生物化学 的酸化を取り入れたプロセスを示している。

筆者らは, 硫化鉱物の浮選工程に㧈ける微生物の有效利 用のための基礎的研究として, T.f.による黄鉄鉱の酸化と それが浮遊性におよぼす影響について検討した ${ }^{38)}$ 。第12図 に示すように，無菌の場合黄鉄鉱の浮遊率は常に高い值を 示しているが， $\mathrm{A} \sim \mathrm{C}$ の 3 種の条件で前培養した T.f. 接種した場合には浸出時間の経過に伴い浮遊率が急速に低 下しており，それは黄鉄鉱の浸出挙動とよく対応している (第 7 眓参照)。またこの抑制作用は，黄鉄鉱表面に打け る親水性硫酸塩皮膜の形成に基づくと判断された。このよ うな知見が，黄鉄鉱と他の硫化鉱物との浮遊分離に適用さ れる日のくることを期待したい。

\section{7.むすび}

鉄や硫黄の酸化によりエネルギーを獲得する独立栄養細 菌について, Thiobacillus ferrooxidans を主体に, その特性やそれによる硫化鉱物の酸化現象に関する従来の 知見の概要を記述した。上記の細菌が発見されて以来 30 年 あまりの間に, 生態的な問題を中心に多くの研究がなされ てきた。しかし，応用面からみると，銅のダンプリーチン グのように自然に生息する細菌に対してより活動しやすい 環境を与えるといつた方法がほとんどで，菌体の積極的な 活用事例はまだきわめて少ない。柵原および松尾鉱山にお

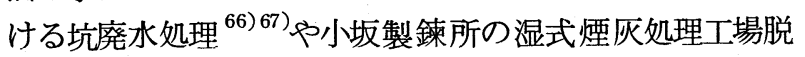
鉄工程への適用 ${ }^{68)}$ は, 数少ない中の注目すべき操業例と いえよう。

細菌を含めた微生物反応は，環境問題やコストなどの面 における利点に反し, 遺伝的変化や環境による変化が起こ りやすく, 制御がむずかしい。そして今後の発展のために は, 適切な制御の確立のほか, より有効な菌種の発見また は改良や, 他の単位操作との効率的組合せ技術の開発など が必要であろう。
1) Brierley, C.L.: Scientific Am., 247 [2], 42 51 (1982) [今泉常正訳 : サイエンス, 10月号, 66〜80(1982)]

2) Tuovinen, O.H. and Kel1y,D.P. : Zeitshrift für Allg. Mikrobiologie, $12[4], 311 \sim 346$ (1972)

3) 伊藤一郎 : バクテリアリーチング, 講談社サイエンティフィ,ク, (1976)

4) Brierley,C.L.: CRC Critical Reviews in Microbiology, $6[11], 207 \sim 262$ (1978)

5) 山根恒夫：生物反応工学, 産業図書, (1980)

6) Buchanan,R.E. and Gibbons,N.E.(ed.): Bergey's Manual of Determinative Bacteriology $8 \mathrm{th}$ ed., Williams \& Wilkins, (1974)

7）今井和民・杉尾 剛·安原照男 - 田野達男 : 日本鉱業会誌, 88 [1018]; 879 884 (1972)

8) Barros, M.E.C., Rawlings, D.E. and Woods, D.R. : Appl. Envir. Microbiol ., 47, 593 595 (1984).

9) Murr,L.E.: Minerals Sci.Eng., 12 [3], 121 189(1980)

10) Duncan, D.W., Walden, C.C. and Trussell, P.C.: Trans. Can. Inst. Mining and Metals, 69, 329 333 (1966)

11) Lacey,D.T. and Lawson, F.: Biotechnol . Bioeng., 12, 29 $\sim 50(1970)$

12) Karaivko, G.I., Kuznetsov, S.I. and Golonizik, A.I.: The Bacterial Leaching of Metals from Ores,p.6, Techn i copy, (1977)

13) 今井和民 : 科学と工業, $57[10], 368 \sim 373$ (1983)

14) Silver, M. : Can.J.Microbiol ., 16, 845 849 (1970)

15) Silver, M. and Torma,A.E. : Can.J.Microbiol., 20, 141 $\sim 147$ (1974)

16) Duncan,D.W. and Drummond,A.D.: Can.J.Earth Sci., 10, $476 \sim 484$ (1973)

17) Murr, L.E. and Berry, V.K.: Hydrometallurgy, 2, 11 24 (1976)

18）角田英男 ·高森隆勝 : 日本鉱業会春季大会講演要旨集， $435 \sim 436$ (1982)

19) Bryner,L.C., Beck, J.V., Davis, D.B. and Wilson, D.G.: Ind. Eng. Chem., 46 [12], 2587 2592 (1954)

20) Torma,A.E.,Walden, C.C. and Branion, R.M.R. : Biotechnol. Bioeng., 12, 501 517 (1970)

21) Leathen,W.W., Kinsel, N.A. and Braley, S.A.: J.Bacteriol., 72, 700 704 (1956)

22) Silverman, M.P. and Lundgren, D.G.: J.Bacteriol., 77, $642 \sim 647$ (1959)

23) Dave,S.R., Natarajan, K.A. and Bha, J.V.: Trans. Indian Inst. Met., 34, 319 323 (1981)

24) Malouf, E.E. and Prater, J.D.: J.Metals, 13 [3], 353 356 (1961)

25) Razzel1,W.E. and Trussel1, P.C.:Appl. Microbiol., 11, $105 \sim 110(1963)$

26) MacDonald, D.G. and Clark, R.H. : Can. J. Chem. Eng., $48,669 \sim 676(1970)$

27) Bryner, L.C., Walker, R.B. and Palmer, R. : Trans.AIME, $238[3], 56 \sim 62(1967)$

28) Razze11,W.E. and Trusse11,P.C. : J.Bacterio1., 85, 595 $\sim 603$ (1963)

29) Torma,A.E., Walden, C. C., Duncan, D.W. and Branion, R.M.R. : Biotechnol. Bioeng., 14, 777 786 (1972)

30) Pinches, A., A 1-Jaid, F.O. and Williams, D.J.A.: Hydrometal lurgy, 2, 87 103 (1976)

31) Kingma Jr, J.G. and Silver, M. : Appl.Envir. Microbiol., 39, 635 641 (1980)

32) Deepak, D. and Das, K.: J.Chem. Tech.Biotechnol., 31, $358 \sim 362$ (1981)

33) Zajic, J.E. and Ng, K.S.: Dev. Ind. Microbiol., 11, $413 \sim 419$ (1970)

34) Landesman, J., Duncan, D.W. and Walden, C.C.: Can. J. Microbiol., 12, 957 964 (1966)

35) Duncan, D.W., Landesman, J. and Walden, C.C. : Can. J. Microbiol., 13, 397 403 (1967)

36) Thakur, D.N., Saroj, K.K. and Gupta,A.: J.Mines Met. Fue 1s, 28, 16 21 (1980)

37) Roy,P.and Mishra, A.K.: Indian J.Experimental Biology, 19, 728 732 (1981) 
38）原田種臣 · 国吉信行 : 日本鉱業会誌, 101 [1173]，719～724 (1985)

39）今井和民：全国地下資源関係学協会合同秋季大会分科研究会資料, E-5 (1974)

40) Andersen, K.J. and Lundgren, D.G.: Can.J.Microbiol., 15, 73 79 (1969)

41) Vorreiter, L. and Madgwick,J.C.: Proc.Australas. Inst.Min. Metall., No.284, 63 66, (1982)

42) Babich,H.and Stotzky, G.: Appl. Envir.Microbiol., 33, 696 705 (1977)

43) Babich,H. and Stotzky, G.: Appl.Envir.Microbiol., 33, $1059 \sim 1066$ (1977)

44) Sugio, T., Domatsu, C., Tano,T.and Imai, K.:Appl . Envir.Microbiol., 48, 461 467 (1984)

45) Tuttle,J.H. and Dugan, P.R.: Can.J.Microbiol., 22, 719 730 (1976)

46) Dugan, P.R. and Ape1, W.A.: Appl Envir. Microbiol. $46,279 \sim 282$ (1983)

47) Onysko, S.J., Kleinmann, R.L.P. and Erickson, P.M. : App1. Envir. Microbiol., 48, 229 231 (1984)

48) Burkin, A.R.: Minerais Sci.Eng., 1, 4 14 (1969)

49) Madgwick,J.C. and Ralph, B.S.: Proc.Australas. Inst. Min. Metal1., No.279, 33 35 (1981)

50) Hiltunen, P., Vuorinen, A., Rehtijärvi,P. and Tuovinen, O.H.: Hydrometall urgy, 7, 147 157 (1981)

51) Murr,L.E. and Mehta, A.P.: Thin Solid Films, 95, $175 \sim 183$ (1982)

52) Ivarson, K.C., Ross, G.J. and Miles, N.M.: Soil Sci. Am.J., 43, 908 912 (1979)

53) Lazaroff, N., Sigal, W. and Wasserman,A.: Appl.Envir. Microbiol., 43, 924 938 (1982)
54) Mehta,A.P. and Murr,L.E.: Hydrometallurgy, 9, 235 $\sim 256$ (1983)

55) Mehta,A.P. and Murr, L.E.: Biotechnol. Bioeng., 24, 919 940 (1982)

56）鴻巣 彬・鈴木光郎・井上千弘・下飯坂潤三 : 日本釷業会春季大会 講演要旨集, $213 \sim 214$ (1984)

57) Silverman, M.P., Rogof $f$ M. H.and Wender, I. :Fuel, 42, 113 124 (1963)

58) Detz, C.M. and Barvinchak, G. : Mining Congress J., No. 7, 75 86 (1979)

59) Hof $f \mathrm{mann}$, M.R., Faust, B.C., Panda, F.A., Koo, H.H. and Tsuchiya, H.M. : Appl. Envir.Microbiol.,42, 259 271 (1981)

60）原田種臣 - 原田種久 - 福田勉丈：日本鉱業会春季大会講演要旨集, $379 \sim 380 \quad(1981)$

61）原田種臣・原田種久：日本釷業会春季大会講演要旨集，205～206 (1983)

62) Torma, A.E. and Subramanian, K.N. : International J. Mineral Processing, 1, 125 134 (1974)

63) Carta, M., Ghiani, M. and Rossi, G.: Proc. Complex Sulphide Ores Conf., 178 185 (1980)

64) Capes, C.E., Mcilhinney, A.E., Sirianni, A.F. and Puddington, I.E.: CIM Bullet in, No.11, 88 91 (1973)

65) Lawrence, R.M. and Brynesteyn, A. : CIM Bulletin, No. $9,107 \sim 110$ (1983)

66）小原芳夫・福田勉丈：日本鉱業会誌，92 [1058]，306～310 (1976)

67) Yabuuchi, E. and Imanaga, Y.: World Mining and Metals Technolngy (Proc. Joint MMIJ-AIME Meeting), 2, $943 \sim 956(1976)$

68）箕浦 潤：日本鉱業会春季大会, 渡辺賞講演 (1985)

(日本鉱業会誌, $101[1169], 379 \sim 402$ (1985))

\section{Oxidation of Sulfide Minerals by Iron-Oxidizing Bacteria}

\section{by Nobuyuki KUNIYOSHI ${ }^{1}$ and Taneomi HARADA ${ }^{2}$}

Thiobacillus ferrooxidans, a chemoautotroph using iron oxidation as an energy source for growth, is attracting the interest in its role in leaching of sulfide minerals.

Many studies on this bacterium have been performed principally in the ecological aspects for over 30 years since the discovery of it. From the results of these studies, more research works regarding following subjects will be necessary for the further progress of the bacterial leaching.

1) Establishment of the suitable environment for the bacterial action,

2) Discovery of more effective species or improvement of strains,

3) Development of effective combination with other unit operations such as flotation and agglomeration.

(1. Graduate Student, Faculty of Science and Engineering, Waseda Univ. Engineering, Waseda Univ.

2. Prof., Dr., Faculty of Science and )

明治37〜 8 年日露戦争にあたり，半島お よび大陸の地質調查が実施されたが，その 報告書には，鉱業技術史上貴重な資料が揭 載されている。眓示の花崗岩製石臼は，わ が国とは異る独特の型式のものである。粉 成技術の発達過程を調べる上で，またとな い手掛りを与えてくれている。なお伊木常 誠農商務技師 ( 元伊木正二会長の厳父 ), 鈴木四郎鉱山監督署技師両名の調查による 「韓国鉱業調查報告」(黄海道, 京畿道, 忠清南道, 平安道南道, 南部) (明治39年 10月刊) 所収で，的場中先生旧蔵の資料で ある。

( 葉賀七三男)
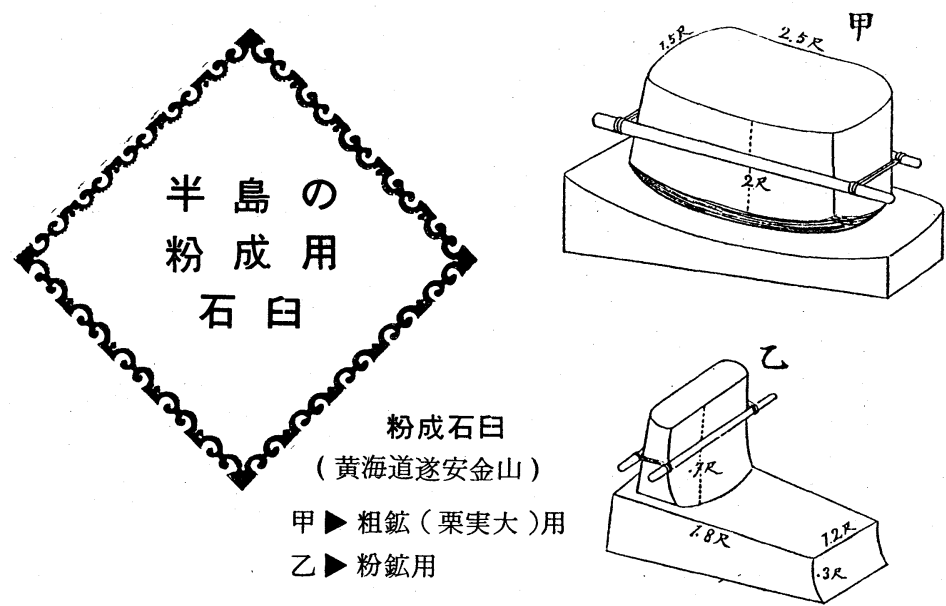